ISSN 1392-3196 / e-ISSN 2335-8947

Zemdirbyste-Agriculture, vol. 101, No. 3 (2014), p. 265-270

DOI 10.13080/z-a.2014.101.034

\title{
Potential of industrial hemp (Cannabis sativa L.) genotypes to suppress weeds
}

\author{
Zofija JANKAUSKIENE ${ }^{1}$, Elvyra GRUZDEVIENE ${ }^{1}$, Sigitas LAZAUSKAS ${ }^{2}$ \\ ${ }^{1}$ Upytė Experimental Station, Lithuanian Research Centre for Agriculture and Forestry \\ Linininkų 3, Upytė, Panevėžys distr., Lithuania \\ E-mail:soja@upyte.lzi.lt \\ ${ }^{2}$ Institute of Agriculture, Lithuanian Research Centre for Agriculture and Forestry \\ Instituto 1, Akademija, Kèdainiai distr., Lithuania
}

\begin{abstract}
Field experiments designed to explore weediness of hemp crops of industrial varieties were carried out at the Upyte Experimental Station of the Lithuanian Research Centre for Agriculture and Forestry in 2010-2012. Eight monoecious industrial hemp varieties from France (5), Poland (2) and Ukraine (1) were grown in a conventional crop rotation after winter wheat. Hemp was sown at a seed rate of $50 \mathrm{~kg} \mathrm{ha}^{-1}$ with $10 \mathrm{~cm}$ interrows at the beginning of May and harvested when the first matured seeds appeared. No mechanical or chemical weed control was applied during hemp growth period. Density of weeds at full hemp emergence was relatively high, with the highest average value of 202 plants $\mathrm{m}^{-2}$ in 2011, the year with relatively high air temperatures at the end of May - beginning of June and adequate rainfall. At hemp harvesting, the highest weed density and above-ground biomass was found in 2010, the year characterised by high temperatures in July and August, in the plots of the USO 31, the variety with the shortest growth period and the lowest plant height. A total of 31 weed species were identified in hemp experiments - 26 species of broad-leaf and grass weeds and 5 species of perennial weeds. At full hemp emergence, weeds typical of spring crops of the region were most abundant: Chenopodium album L. dominated in 2010, Veronica arvensis L. in 2011, while in 2012 the domination was shared by the four weed species Lamium purpureum L., Thlaspi arvense L., V. arvensis and Poa annua L. At harvest, in total 8 weed species were found; however, only C. album and partly Polygonum aviculare L. were relatively abundant in all years.
\end{abstract}

Key words: biomass, Chenopodium album, density, weed species.

\section{Introduction}

Hemp (Cannabis sativa L.) is a crop traditionally grown for fibres and seeds. Its production as an energy crop has been under consideration recently (Sipos et al., 2010; Bellido et al., 2014). Eighty years of studies in Italy suggest that hemp shows broad adaptability to different climates, low nitrogen and herbicide requirements, high drought tolerance, and positive rotational effects (Zatta et al., 2012). Fast growth and rich foliage provide hemp advantage in competition with weeds (Poisa, Adamovics, 2010; Rehman et al., 2013). Under the climate conditions of Central and South Eastern Europe, hemp sown for fibre usually reaches a height of $1.5-3.0 \mathrm{~m}$, while in our previous trials the average height of hemp variety 'Beniko' was $2.8 \mathrm{~m}$ (Jankauskiené, Gruzdevienè, 2010). Although it is generally accepted that hemp can efficiently suppress weeds, research evidence on hemp and weed competition is rather limited.

A number of studies show the importance of crop density in hemp-weed competition. In the field trials in Australia, weed above-ground dry biomass decreased from $23.2 \mathrm{~g} \mathrm{~m}^{-2}$ at a crop density of 100 plants $\mathrm{m}^{-2}$ to $6.5 \mathrm{~g} \mathrm{~m}^{-2}$ at a density of 200 plants $\mathrm{m}^{-2}$ (Hall et al., 2014).
Experiments in the Netherlands demonstrated that hemp crop can effectively suppress weeds and no herbicides are needed, with the exception of very low (10 or 30 plants per $\mathrm{m}^{2}$ ) density crops (van der Werf et al., 1995). Other authors also suggest that hemp at sufficient density requires no herbicide applications (Prade, 2011; Reeves, 2012). In our experiments performed in 2006 and 2007, seed rate had a significant influence on crop weediness at harvest (Jankauskienè, Gruzdevienè, 2009).

An opinion that hemp can be grown to reduce the level of field infestation with annual as well as some perennial weeds was expressed by a number of researchers (Struik et al., 2000; Sipos et al., 2010). In Canada, hemp is successfully grown with the aim of controlling thistles (Cirsium arvense L.), and attempts to control couch grass (Elytrigia repens L.) were also mentioned. In the Netherlands, hemp was mentioned among the most efficient crops in yellow nutsedge (Cyperus esculentus L.) control (Lotz et al., 1991). However, wild buckwheat (Fallopia convolvulus (L.) Löve), common wild oat (Avena fatua L.), colza (Brassica napus L.), goosefoot (Chenopodium album L.) and some other plants are 
considered as problematic weeds in hemp crops (Hemp Agronomy..., 2006). Morning glory (Ipomoea spp. L.) is a particular problem in hemp seed production because its seed is the same size as hemp and is very difficult to separate by screening (Ehrensing, 1998).

Although available empirical studies provide indication on some weeds that can cause severe yield losses in hemp crops, information on hemp interaction with weed communities of local agroecosystems under different management is very scarce. Study by Lososova et al. (2008) showed that the list of most abundant weeds in the Czech Republic corresponds very well to the lists of other countries of Central and Northern Europe and includes some species problematic for hemp: Polygonum aviculare, F. convolvulus, C. album can be found on agricultural fields throughout Europe independently of climatic conditions. Hyvonen et al. (2011) suggest that weed species richness and abundance depend on land use type and region and tend to decline from fallows and low-input to conventionally cultivated land use type and from south to north. Moreover, a study of Alignier et al. (2013) showed importance of management factor - the best variable to explain the occurrence of more than half of the tested weed species was the history of management practices over the last five years.

Genetic background of hemp can have a profound effect on crop phenology, growth and ability to compete with weeds. Breeding programs, especially after success in selection of low-THC genotypes, resulted in a great diversity of hemp genotypes with regard to biological characteristics, adaptability to a range of climate conditions and suitability for specific uses. Availability of a wide range of cultivars of different duration and photoperiod sensitivity leads to uncertainty in prediction of crop development behaviour and management decisions, especially at higher latitudes, as was pointed by Amaducci et al. (2012). Experimental evidence regarding ability of different hemp varieties to suppress weeds is scarce and fragmentary. Although hemp once was a traditional plant for agricultural landscapes of countries of higher latitudes including Lithuania, introduction of new hemp genotypes brings new research challenges regarding competition of this crop with local weed communities. Hemp growth patterns could differ between genotypes, so different varieties could have different potential to suppress weeds.

The main task of our study was to assess weediness of industrial hemp grown in a conventional crop rotation and to explore varietal influence on this indicator.

\section{Materials and methods}

Field experiments were conducted at the Upyte Experimental Station of the Lithuanian Research Centre for Agriculture and Forestry in 2010-2012 on an EutriEndohypogleyic Cambisol (CMg-n-w-eu). The properties of the soil arable layer were as follows: $\mathrm{pH}_{\mathrm{KCl}}-6.7-7.7$, humus - 1.89-2.33\%, available phosphorus $\left(\mathrm{P}_{2} \mathrm{O}_{5}\right)-$ $137-245 \mathrm{mg} \mathrm{kg}^{-1}$, available potassium $\left(\mathrm{K}_{2} \mathrm{O}\right)-122-152$ $\mathrm{mg} \mathrm{kg}^{-1}$ (A-L method). In the crop rotation hemp followed winter wheat. In autumn, the soil was ploughed and in spring it was cultivated and rolled. No mechanical or chemical weed control was applied during hemp growth period. Fertilizers (200 kg of complex $\mathrm{N}_{7} \mathrm{P}_{19} \mathrm{~K}_{29} \mathrm{~S}_{3}$ and $200 \mathrm{~kg}$ of $\mathrm{N}_{16} \mathrm{P}_{16} \mathrm{~K}_{16}$ ) were broadcast and incorporated into the soil using a cultivator before hemp drilling.

As monoecious hemp varieties produce a more homogeneous crop and higher seed yield than dioecious (Amaducci, Gusovius, 2010), eight monoecious cultivars were selected for the trials. The varieties 'Beniko' and 'Bialobrzeskie' are considered as semi-early in Poland, the country of their origin. The French variety 'Epsilon $68^{\prime}$ ' is late-ripening in France, the varieties 'Felina 32' 'Santhica 27' (both are of French origin) - semi-late in France, the variety 'Futura 75 ' - very late-ripening in France, while 'Fedora 17 ' is early-ripening, and the variety USO 31 (of Ukrainian origin) is known as very early variety in France. According to Cosentino et al. (2012), variety 'Futura 75 ' belongs to the medium maturity group.

Hemp was sown at a seed rate of $50 \mathrm{~kg} \mathrm{ha}^{-1}$ with $10 \mathrm{~cm}$ interrows by a sowing-machine SLN-1.6 ("Bezhetskselmash", Russia) at the beginning of May. Hemp was harvested when the first matured seeds appeared (in September or October, depending on the year and variety). The size of experimental plots was $20 \mathrm{~m}^{2}(2 \times 10 \mathrm{~m})$; harvested area $-8 \mathrm{~m}^{2}(1 \times 8 \mathrm{~m})$. Experimental plots were arranged into three randomised blocks. Hemp and weed density counts were performed twice: 1) at full hemp emergence and 2) at harvest. For this purpose microplots of $0.25 \mathrm{~m}^{2}(0.5 \times 0.5 \mathrm{~m})$ were established in each experimental plot. At harvest, weeds from all microplots were pulled, air-dried biomass was assessed.

Meteorological conditions. The weather conditions varied among experimental years; however, all the three growth seasons were relatively warm and abundant in rainfall. Thermal and irrigation conditions during the crop growth season could be described by a widely used agrometeorological indicator - Selianinov's hydrothermal coefficient HTC $=\Sigma \mathrm{p} / 0.1 \Sigma \mathrm{t}$, where: $\Sigma \mathrm{p}$ - total precipitation $(\mathrm{mm})$ sum during the given period, the temperature above $10^{\circ} \mathrm{C} ; \Sigma \mathrm{t}-$ total sum of active temperatures $\left({ }^{\circ} \mathrm{C}\right)$ of the same period. If HTC $>1.6-$ the irrigation is excessive, HTC $=1.0 \ldots 1.5-$ optimal irrigation, $\mathrm{HTC}=0.9 \ldots 0.8-$ weak drought, $\mathrm{HTC}=$ $0.7 \ldots 0.6$ - moderate drought (arid), HTC $=0.5 \ldots 0.4-$ heavy drought, HTC $<0.4$ - very heavy drought (Dirsè, Taparauskienè, 2010).

According to the HTC data presented in Figure, good moisture supply in May 2010 favoured hemp and weed seed germination. The $1^{\text {st }}$ ten-day period of June was droughty, the $2^{\text {nd }}-$ excessive in rainfall and the $3^{\text {rd }}$ close to optimal. The weather in July and August was warm with adequate rainfall - conditions favourable for hemp growth and weed survival. In May 2011, moisture conditions were conducive to hemp and weed seed germination. In June, moderate drought occurred; however, the rest of the hemp growth period was abundant in rainfall. Due to warm and rainy weather in July and August, hemp flowering and ripening period was delayed. In 2012, germination and beginning of growth of hemp proceeded under the abundant moisture supply. During 
the major part of July moisture availability was close to optimal; however, beginning of August and middle of September were relatively humid.

Statistical analysis. The experimental data were analysed by ANOVA for randomised block design. Assumptions for ANOVA were checked and combined analyses of data from three years' experiments were performed as described by Petersen (1994). Data of weed density and biomass were transformed, according to the recommended procedures, using equation $\mathrm{Y}=\operatorname{Sqr}(\mathrm{x}+1)$; however, means on the original scales are reported (Onofri et al., 2010). Differences between means were compared using Fisher's protected LSD and significant differences are denoted by asterisk $(*-$ for $p<0.05)$. Conventional correlation and regression analyses were done to estimate interdependence between weed abundance and hemp yield variables.

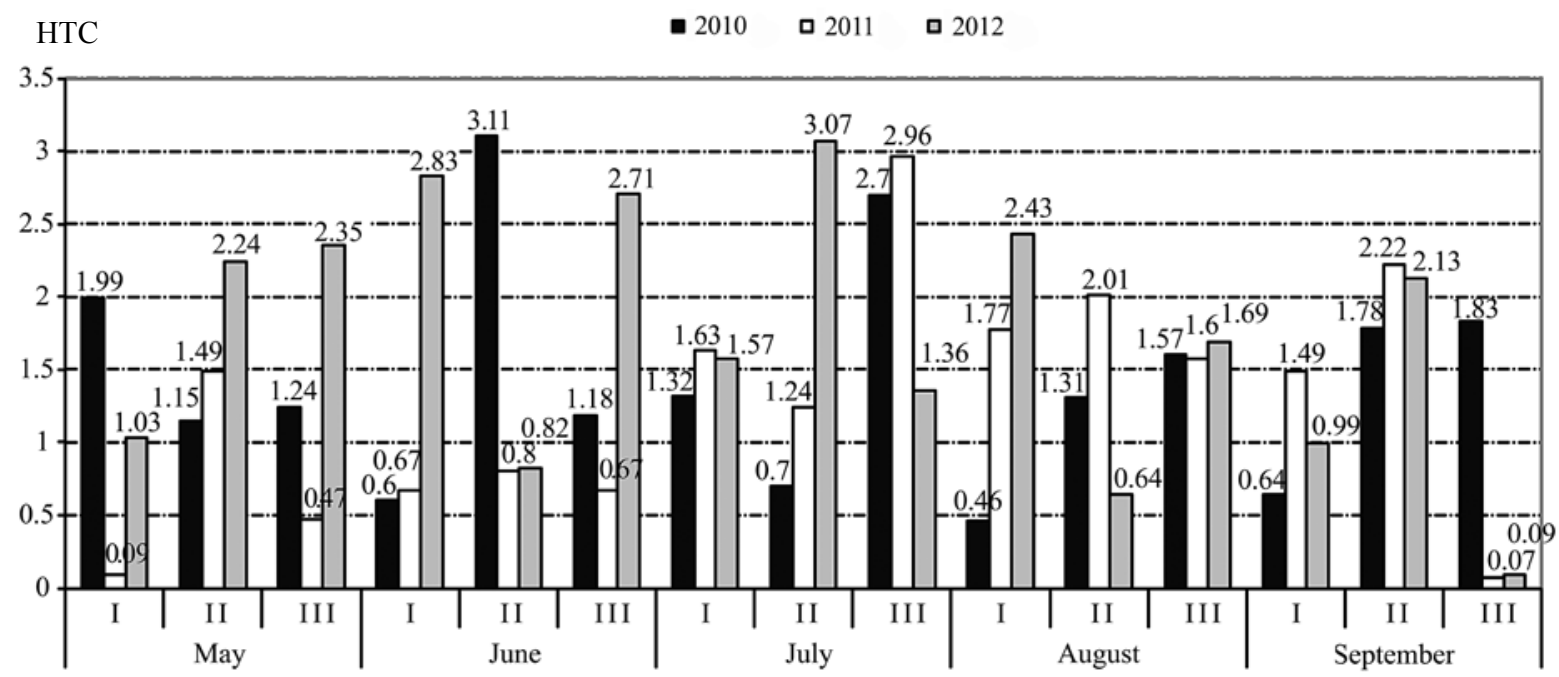

Figure. Hydrothermal coefficient (HTC) during hemp vegetation period (Upyte, 2010-2012)

\section{Results and discussion}

Weed density. The average density of weeds (133-202 plants $\mathrm{m}^{-2}$ ) in our experiments at full hemp emergence was relatively high - higher than measured in our previous experiments performed in 2006 and 2007 (Jankauskiene, Gruzdevienè, 2009). Although the reasons of differences among two series of experiments are not completely clear, we assume that local soil weed seed bank and weather conditions, mainly temperature and rainfall, were the most relevant factors to consider.

The highest average density of weeds (202 plants $\mathrm{m}^{-2}$ ) was found in 2011 (Table 1). We assume, that relatively high air temperatures at the end of May and especially at the beginning of June (daily mean temperature of the first ten-day period of June was $21.6^{\circ} \mathrm{C}$ ) along with adequate rainfall, provided favourable conditions for weed seed germination. There was no significant variety effect on weed density at full hemp emergence, suggesting that at early growth stages differences among hemp varieties in ability to compete with weeds were not fully manifested. This assumption is in a good agreement with crop biology - rapid growth of hemp starts from the appearance of the $6^{\text {th }}$ set of leaves - BBCH stage 1012 (Mediavilla et al., 1998).

Density of weeds at harvest was several times lower than that at full emergence and varied significantly among years. Interaction between year and variety for this indicator was significant, thus data are presented for each year. The higher rate of survival of weeds in 2010 can be partly explained by specific weather conditions. Very high temperatures in July and August (respectively $5.1^{\circ} \mathrm{C}$ and $3.5^{\circ} \mathrm{C}$ above climate normal) accelerated development of hemp and resulted in lower plant height and earlier harvest, especially of variety USO 31. At the same time competition between plants and weeds for water was low due to abundant rainfall. Under such conditions differences between varieties were significant and the highest density of weeds was found in USO 31, characterised by the lowest canopy height and the shortest growth period. Significant varietal effect was also found in 2012 - the highest weed density at harvest was found in USO 31 and 'Beniko', varieties considered as early. These results suggest that earliness of hemp variety is an important factor to consider in weed management.

Table 1. Density of weeds at full hemp emergence and at harvest

Upytė Experimental Station, 2010-2012

\begin{tabular}{lcccccc}
\hline \multirow{2}{*}{ Variety } & \multicolumn{3}{c}{$\begin{array}{c}\text { At full emergence } \\
\text { plants m-2 }\end{array}$} & \multicolumn{3}{c}{$\begin{array}{c}\text { At harvest } \\
\text { plants m-2 }\end{array}$} \\
\cline { 2 - 7 } & 2010 & 2011 & 2012 & 2010 & 2011 & 2012 \\
\hline 1. 'Beniko' & 143 & 173 & 126 & 23 & 6 & $13 * b$ \\
2. 'Bialobrzeskie' & 118 & 183 & 174 & 21 & 7 & 2 \\
3. 'Epsilon 68' & 150 & 216 & 166 & 35 & 5 & 1 \\
4. 'Fedora 17' & 115 & 177 & 156 & 41 & 4 & 0 \\
5. 'Felina 32' & 134 & 175 & 191 & 21 & 5 & 3 \\
6. 'Futura 75' & 125 & 225 & 184 & 36 & 3 & 1 \\
7. 'Santhica 27' & 124 & 245 & 161 & 37 & 3 & 2 \\
8. USO 31 & 158 & 219 & 141 & $55 * a$ & 7 & $7 * b$ \\
$\quad$ Average & 133 & 202 & 162 & 34 & 6 & 4 \\
\hline
\end{tabular}

*a - significant difference between treatments $1-7$ and 8 ; *b significant difference between treatments 2-7 and 1,8 
Reduction of weed density during period from full hemp emergence to harvest varied substantially among years, with the lowest average value $74 \%$ measured in 2010. On the contrary, this indicator was very high (close to 97\%) and similar in 2011 and 2012. Significant positive linear correlation $(r=0.86$ in 2010 , $r=0.99$ in 2011 and $r=0.99$ in 2012) was found between density of weeds at full hemp emergence and reduction of weed density: higher crop weediness in spring - higher reduction of weediness.

Weed species. Altogether 31 weed species were found in our experiments at full hemp emergence: 26 annual broad-leaf and grass weed species and only 5 species of perennial weeds. However, only a few species were abundant in all experimental years. Chenopodium album prevailed in 2010 and Veronica arvensis in 2011. In 2012, the four dominant weed species were: Lamium purpureum, Thlaspi arvense, V. arvensis and Poa annua. We can see some difference between this list and the list of predominant weed species in our previous trials with hemp, where the dominant weeds were Euphorbia helioscopia L., Viola arvensis Murr., Fallopia convolvulus (L.) Löve, Polygonum aviculare L., C. album L. and Fumaria officinalis L. (Jankauskienè, Gruzdevienè, 2009).

In total, 8 weed species were identified at hemp harvest during three years of experiments. C. album, Poa annua and Polygonum aviculare were rather common in autumn. In contrast to other species which were abundant at full hemp emergence, C. album was able to retain its predominant position until harvest of hemp and to dominate over other weeds in the majority of experimental plots. Poa annua occurred occasionally but in all experimental years. Papaver rhoeas L., Trifolium pratense L., Solanum nigrum L., Viola arvensis Murr., Stellaria media L. occurred only occasionally. In 2009, Polygonum aviculare was frequent also. These weeds were also abundant in spring barley crop in the study performed in 2009 (Braziene et al., 2009), thus we assume, that these species are typical of this area rather than specific of hemp crop. In the mentioned above study, $P$. aviculare was numerous, especially near headland; however, biomass was relatively low. In contrast, C. album was not so numerous; however, biomass per plant was high.

Chenopodium album was the dominant weed at harvest in both of our experiments with hemp (20062007 and 2010-2012), thus we can assume that for this generalist weed all crop types grown in this area in crop rotation are 'suitable' habitats and it is more the crop phenology that is of importance for weed occurrence in such cases, as was suggested by Alignier et al. (2013). Experimental evidence regarding hemp and weed competition is very limited; however, robust research information is available on other tall, highly productive crop with long growth period - maize. In Fried et al. (2010) study the generalist weed $C$. album was the dominant species in both maize monoculture and crop rotation, while other generalist species $-P$. aviculare was among dominant species in rotations. The C. album is widely distributed all over the world. In Europe it occurs with high abundances along the climate gradient from
South Italy up to Finland (Radics et al., 2004). Plants of $C$. album produce large amounts of heteromorphic seeds - a feature is thought to be a selective advantage for plants inhabiting harsh and heterogeneous areas and relevant for adaptation to variable environments (Yao et al., 2010). Although C. album has been a target for weed control for decades, it remains one of the most common and abundant species, e.g., in soil seed bank samples taken from organic and conventional spring cereal fields in Finland during surveys conducted both in 1960s and 2007-2009 (Salonen et al., 2011).

Although 31 weed species were identified in hemp crop during the study period, on average 7-13 species were found per one treatment plot at full hemp emergence and only 1-3 at harvest (Table 2). These results seem typical and correspond well with a view that nearly two thirds of the total species number occur rarely, only on less than $10 \%$ of the observed fields (Radics et al., 2004). Variation of this indicator among years was rather low and observed differences among treatments seem non-regular.

Table 2. Average number of weed species at full hemp emergence and at harvest

Upytė Experimental Station, 2010-2012

\begin{tabular}{lcccccc}
\hline \multirow{2}{*}{ Variety } & \multicolumn{3}{c}{$\begin{array}{c}\text { At full emergence } \\
\text { species } \mathrm{m}^{-2}\end{array}$} & \multicolumn{4}{c}{$\begin{array}{c}\text { At harvest } \\
\text { species } \mathrm{m}^{-2}\end{array}$} \\
\cline { 2 - 7 } & 2010 & 2011 & 2012 & 2010 & 2011 & 2012 \\
\hline 1. 'Beniko' & 11 & 9 & 12 & 2 & 1 & $<1$ \\
2. 'Bialobrzeskie' & 11 & 10 & 12 & 2 & 1 & $<1$ \\
3. 'Epsilon 68' & 12 & 10 & 12 & 2 & 2 & $<1$ \\
4. 'Fedora 17' & 10 & 11 & 12 & 2 & 1 & $<1$ \\
5. 'Felina 32' & 10 & 10 & 11 & 1 & 1 & $<1$ \\
6. 'Futura 75' & 7 & 12 & 12 & 3 & 1 & 2 \\
7. 'Santhica 27' & 9 & 13 & 12 & 2 & 1 & $<1$ \\
8. USO 31 & 11 & 11 & 13 & 3 & 2 & 1 \\
$\quad$ Average & 10 & 11 & 12 & 2 & 1 & $<1$ \\
\hline
\end{tabular}

Weed biomass. The above-ground biomass of weeds was measured at hemp harvesting and varied notably among years and varieties (Table 3 ).

Table 3. Weed biomass at hemp harvest Upyte Experimental Station, 2010-2012

\begin{tabular}{lccc}
\hline \multirow{2}{*}{ Varieties } & \multicolumn{3}{c}{ Weed biomass g m${ }^{-2}$} \\
\cline { 2 - 4 } & 2010 & 2011 & 2012 \\
\hline 1. 'Beniko' & 18.3 & 12.8 & 1.4 \\
2. 'Bialobrzeskie' & 12.2 & 7.2 & 0.6 \\
3. 'Epsilon 68' & 15.1 & 12.4 & 0.0 \\
4. 'Fedora 17' & 9.2 & 7.5 & 0.0 \\
5. 'Felina 32' & 14.5 & 18.0 & 0.2 \\
6. 'Futura 75' & 15.7 & 4.3 & 0.2 \\
7. 'Santhica 27' & 18.4 & 3.9 & 0.1 \\
8. USO 31 & $55.6 *$ & 4.5 & 2.0 \\
$\quad$ Average & 19.9 & 8.8 & 0.6 \\
\hline
\end{tabular}

* - significant difference between treatments $1-7$ and 8 
Generally, there was significant correlation between weed density and biomass at hemp harvest $(r=0.64, p<0.01)$, thus some observations made for weed density are true also for weed biomass. Interaction between year and variety was significant; therefore weed biomass data are presented and discussed separately for each year. Like weed density, weed biomass in 2010 was higher than in other years and the highest weed biomass was found in the plots of hemp variety USO 31 . However, in 2012 somewhat higher weed biomass values in plots of 'Beniko' and USO 31 varieties were non-significant.

\section{Conclusions}

1. Density of weeds at full hemp emergence was relatively high, with the highest average value of 202 plants $\mathrm{m}^{-2}$ in 2011 , the year with relatively high air temperatures at the end of May - beginning of June and with adequate rainfall. However, no significant differences were found between varieties.

2. Significant year and variety interaction was found for weed density and above-ground biomass at hemp harvesting. These indicators were much higher in 2010, the year with high temperatures in July and August, in the plots of USO 31 characterised by the shortest growth period and the lowest plant height.

3. In total 31 weed species were identified in hemp experiments - 26 species of annual broad-leaf and grass weeds and 5 species of perennial weeds. At full hemp emergence weeds typical of spring crops of the region were most abundant: Chenopodium album dominated in 2010, Veronica arvensis in 2011, while in 2012 the four prevailing weed species were Lamium purpureum, Thlaspi arvense, $V$. arvensis and Poa annua. At harvest, in total 8 weed species were found; however, only C. album and partly Polygonum aviculare were relatively abundant in all years.

4. In our experiments, hemp was incorporated into conventional crop rotation after winter wheat, and in general showed high potential to compete with most of the weed species typical of spring crops under the local climate and soil conditions. However, C. album showed exceptional capacity to survive the competition with hemp.

\section{Acknowledgments}

The research was part of the long-term programme "Biopotential and Quality of Plants for Multifunctional Use" of Lithuanian Research Centre for Agriculture and Forestry.

Received 14102013

Accepted 20082014

\section{References}

Alignier A., Ricci B., Biju-Duval L., Petit A. 2013. Identifying the relevant spatial and temporal scales in plant species occurrence models: the case of arable weeds in landscape mosaic of crops. Ecology Complexity, 15: 17-25 http://dx.doi.org/10.1016/j.ecocom.2013.01.007
Amaducci S., Gusovius H.-J. 2010. Hemp - cultivation, extraction and processing. Müssing J. (ed.). Industrial application of natural fibres: properties and technical application, p. 109-134

Amaducci S., Colauzzi M., Bellocchic G., Cosentino S. L., Pahkalae K., Stomphf T. J., Westerhuisf W., Zatta A., Venturi G. 2012. Evaluation of a phenological model for strategic decisions for hemp (Cannabis sativa L.) biomass production across European sites. Industrial Crops and Products, 37: 100-110 http://dx.doi.org/10.1016/j.indcrop.2011.11.012

Bellido L. L., Wery J., Lopez-Bellido R. J. 2014. Energy crops: prospects in the context to sustainable agriculture. European Journal of Agronomy, 60: 1-12 http://dx.doi.org/10.1016/j.eja.2014.07.001

Brazienė Z., Repšienė R., Skuodienė R., Gruzdevienė E., Česnulevičienè R., Žèkaitè V. 2009. The diversity of segetal flora in spring barley crops and assessment according to Ellenberg indicator values in different sites of Lithuania. Vagos, 88 (41): 7-13 (in Lithuanian)

Cosentino S. L., Testa G., Scordia D., Copani V. 2012. Sowing time and prediction of flowering of different hemp (Cannabis sativa L.) genotypes in southern Europe. Industrial Crops and Products, 37: 20-33 http://dx.doi.org/10.1016/j.indcrop.2011.11.017

Dirsè A., Taparauskienè L. 2010. Humidity fluctuations in plant vegetation periods and a comparison of its assessment methods. Žemès ūkio mokslai, 17 (1-2): 9-17 (in Lithuanian)

Ehrensing D. T. 1998. Feasibility of industrial hemp production in the United States Pacific Northwest $<\mathrm{http}$ ://extension. oregonstate.edu/catalog/html/sb/sb681/\#Weed $\% 20$ control> [accessed 1102 2014]

Fried G., Petit S., Reboud X. 2010. A specialist-generalist classification of the arable flora and its response to changes in agricultural practices. BMC Ecology $<$ http://www. biomedcentral.com/1472-6785/10/20> [accessed 2807 2014]

Hall J., Bhattarai S. P., Midmore D. J. 2014. Effect of industrial hemp (Cannabis sativa L.) planting density on weed suppression, crop growth, physiological responses, and fibre yield in the subtropics. Renewable Bioresources http://dx.doi.org/10.7243/2052-6237-2-1

Hemp Agronomy 101. 2006. <http://www.votehemp.com/PDF/ HempAgronomy101version2006.pdf $>$ [accessed 1402 2014]

Hyvonen T., Glemnitz M., Radics L., Hoffmann J. 2011. Impact of climate and land use type on the distribution of Finnish casual arable weeds in Europe. Weed Research. 51 (2): 201 208 http://dx.doi.org/10.1111/j.1365-3180.2010.00826.x

Jankauskienè Z., Gruzdevienė E. 2009. The investigation of weediness in the agrocenosis of industrial hemp (Canabis sativa L.). Vagos, 83 (36): 23-29 (in Lithuanian)

Jankauskienè Z., Gruzdevienè E. 2010. Evaluation of Cannabis sativa cultivars in Lithuania. Zemdirbyste-Agriculture, 97, (3): 87-96 (in Lithuanian)

Lososova Z., Chytry M., Kuhn I. 2008. Plant attributes determining the regional abundance of weeds on central European arable land. Journal of Biogeography, 35: 177-187

Lotz L. A., Groeneveld P. R. M. W., Habekotte B., van Oene H. 1991. Reduction of growth and reproduction of Cyperus esculentus by specific crops. Weed Research. 31: 153-160 http://dx.doi.org/10.1111/j.1365-3180.1991.tb01754.x

Mediavilla V., Jonquera M., Schmid-Slembrouck I., Soldati A. 1998. Decimal code for growth stages of hemp (Cannabis sativa L.). Journal of the International Hemp Association, 5 (2): $65,68-74$

Onofri A., Carbonell E. A., Piepho H.-P., Mortimer A. M., Cousens R. D. 2010. Current statistical issues in Weed Research. Weed Research. 50: 5-24 http://dx.doi.org/10.1111/j.1365-3180.2009.00758.x

Petersen R. G. 1994. Agricultural field experiments. Design and analyses. New York, USA, 409 p. 
Poisa L., Adamovics A. 2010. Hemp (Cannabis sativa L.) as an environmentally friendly energyplant. Environmental and Climate Technologies, 5: 80-85

Prade T. 2011. Industrial hemp (Cannabis sativa L.) - a highyielding energy crop. Doctoral Thesis, Swedish University of Agricultural Sciences. Alnarp, Sweden, 93 p.

Radics L., Glemnitz M., Hoffmann J., Czimber G. 2004. Composition of weed floras in different agricultural management systems within the European climatic gradient. $6^{\text {th }}$ EWRS Workshop on physical and cultural weed control. Lillehammer, Norway, 58-68

Reeves T. A. 2012. Hemp: an agricultural super-crop held hostage, $16 \mathrm{p}$.

Rehman M. S. U., Rashid N., Saif A., Mahmood T., Han J.-I. 2013. Potential of bioenergy production from industrial hemp (Cannabis sativa): Pakistan perspective. Renewable and Sustainable Energy Reviews, 18: 154-164 http://dx.doi.org/10.1016/j.rser.2012.10.019

Salonen J., Hyvonen T., Jalli H. 2011. Composition of weed flora in spring cereals in Finland - a fourth survey. Agricultural and Food Science, 20: 245-261

http://dx.doi.org/10.2137/145960611797471534
Sipos B., Kreuger E., Svensson S.-E., Reczey K., Bjornsson L., Zacchi G. 2010. Steam pretreatment of dry and ensiled industrial hemp for ethanol production. Biomass and Bioenergy, 34 (12): 1721-1731 http://dx.doi.org/10.1016/j.biombioe.2010.07.003

Struik P. C., Amaducci S., Bullard M. J., Stutterheim N. C., Venturi G., Cromack H. T. H. 2000. Agronomy of fibre hemp (Cannabis sativa L.) in Europe. Industrial Crops and Products, 11: 107-118 http://dx.doi.org/10.1016/S0926-6690(99)00048-5

van der Werf H. M. G., van Geel W. C. A., Wijlhuizen M. 1995. Agronomic research on hemp (Cannabis sativa L.) in the Netherlands, 1987-1993. Journal of the International Hemp Association, 2 (1): 14-17

Yao S., Lan H., Zhang F. 2010. Variation of seed heteromorphism in Chenopodium album and the effect of salinity stress on the descendants. Annals of Botany, 105: 1015-1025 http://dx.doi.org/10.1093/aob/mcq060

Zatta A., Monti A., Venturi G. 2012. Eighty years of studies on industrial hemp in the Po valley (1930-2010). Journal of Natural Fibers, 9: 180-196 http://dx.doi.org/10.1080/15440478.2012.706439

ISSN 1392-3196 / e-ISSN 2335-8947

Zemdirbyste-Agriculture, vol. 101, No. 3 (2014), p. 265-270

DOI $10.13080 / \mathrm{z}-\mathrm{a} .2014 .101 .034$

\section{Sẻjamosios kanapès (Cannabis sativa L.) pluoštinių genotipų piktžolių stelbimo potencialas}

\section{Z. Jankauskienè $\dot{1}^{1}$ E. Gruzdevienè ${ }^{1}$, S. Lazauskas ${ }^{2}$}

${ }^{1}$ Lietuvos agrarinių ir miškų mokslų centro Upytès bandymų stotis

${ }^{2}$ Lietuvos agrarinių ir miškų mokslų centro Žemdirbystès institutas

\section{Santrauka}

Lietuvos agrarinių ir miškų mokslų centro Upytės bandymų stotyje 2010-2012 m. atlikti įvairių veislių pluoštinių kanapių pasèlio piktžolètumo tyrimai. Aštuonių veislių iš Prancūzijos (5), Lenkijos (2) ir Ukrainos (1) kanapès buvo augintos sèjomainoje po žieminių kviečių. Kanapès sètos gegužès mėnesio pradžioje $50 \mathrm{~kg} \mathrm{ha}^{-1}$ sèklos $10 \mathrm{~cm}$ tarpueiliais, nuimtos subrendus pirmosioms sèkloms. Kanapių vegetacijos laikotarpiu cheminès ar mechaninès piktžolių kontrolès priemonès netaikytos. Kanapèms visiškai sudygus bandymų pasėlio piktžolètumas buvo didelis, didžiausias - vidutiniškai 202 augalai $\mathrm{m}^{-2}$ - nustatytas $2011 \mathrm{~m}$., kai gegužès pabaigoje-birželio pradžioje vyravo sąlygiškai šilti ir drègni orai. Derliaus nuemimo metu daugiausia piktžolių ir didžiausia jų masė nustatyta $2010 \mathrm{~m}$., kai liepos ir rugpjūčio mènesiais vyravo labai šilti orai, veislès USO 31, pasižyminčios trumpa vegetacija ir nedideliu augalų aukščiu, kanapių laukeliuose. Tyrimų metais kanapių pasèlyje iš viso buvo rastos 31 rūšies piktžolès - 26 iš jų priklausẻ vienametèms plačialapėms ir varpinėms, 5 - daugiametèms. Kanapèms sudygus vyravo būdingos regiono vasarinių augalų pasèliams piktžolès: $2010 \mathrm{~m}$. - baltoji balanda (Chenopodium album L.), 2011 m. - dirvinè veronika (Veronica arvensis L.), 2012 m. - keturių rūšiu piktžolès: raudonžiedè notrelè (Lamium purpureum L.), trikertè žvaginè (Thlaspi arvense L.), dirvinè veronika (Veronica arvensis L.) ir vienametè miglè (Poa annua L.). Derliaus nuèmimo metu iš viso buvo rastos 8 rūšių piktžolès, tačiau visais tyrimų metais gausiau buvo paplitusios tik C. album ir iš dalies Polygonum aviculare L.

Reikšminiai žodžiai: biomasè, Chenopodium album, piktžolètumas, rūšis. 